\title{
Major bottlenecks for the restoration of natural forests in Chile
}

\author{
Jan R. Bannister ${ }^{1,2} \odot$, Rodrigo Vargas-Gaete ${ }^{3}$, Juan F. Ovalle ${ }^{4}$, Manuel Acevedo, \\ Andrés Fuentes-Ramirez ${ }^{3,6}$, Pablo J. Donoso ${ }^{7}$, Alvaro Promis ${ }^{4}$, Cecilia Smith-Ramírez ${ }^{6,7,8}$ (1)
}

\begin{abstract}
International agreements combined with the recent Chilean Forestry Policy (2015-2035) represent a challenge and an opportunity for forest landscape restoration in Chile. Nevertheless, restoring over $\mathbf{5 0 0 , 0 0 0}$ ha using mainly native species seems like a daunting task by 2035 . Here, we discuss the three major bottlenecks that currently constrain the restoration efforts of forest ecosystems in Chile. First, Chile urgently needs a national strategic plan for forest landscape restoration, which should take into account mid- and long-term goals. There is also a need to prioritize resource allocation for efficient use, promoting the creation of economic subsidies for restoration that consider different types of forest ecosystems. Second, there is a great need for better nursery protocols in plant production as well as to strengthen educational programs for professional and technical training, given the lack of high-quality personnel in Chilean nurseries. This would help increase the currently limited national plant supply, improving quality and increasing the diversity of native species suitable for forest restoration. Lastly, taking advantage of novel eco-technological tools and promoting innovative plantation design would help to overcome the usually deficient results in the establishment phase, leading to higher survival rates and promoting better performance of native species. Beyond current experiments that are relatively efficient on a small spatial scale, the practice of forest restoration needs to become massive and successful at a landscape scale. More and better applied research is crucial for improving the impact of forest landscape restoration, so that Chile can achieve its forest restoration challenge in the next decade.
\end{abstract}

Key words: local environmental policies, native species, nurseries, restoration practice, seedling establishment

\section{Introduction}

According to international agreements, Chile must restore $15 \%$ of its degraded ecosystems by the year 2020 (Aichi targets). Furthermore, Chile has committed to reforest at least 100,000 ha by the year 2030 using mainly native species (Paris Climate Agreement COP21, New York Declaration of Forests, Initiative 20×20). The new Chilean Forestry Policy (2015-2035) matches these international commitments, and goes even further, aiming at restoring 500,000 ha of degraded or fragmented ecosystems within priority areas (CONAF 2015). These targets represent an enormous challenge for Chile in terms of governance, implementation, and long-term monitoring.

Forest restoration is especially challenging in regions with an increasing rate of anthropogenic disturbances with uncertain synergies (Mandle et al. 2011). A striking example of altered disturbance regimes involves changes in the frequency, severity, and seasonality of anthropogenic fires (e.g. south-central Chile; Ubeda \& Sarricolea 2016). During the summer of 2017, the worst catastrophic wildfires in the last 50 years occurred in south-central Chile, affecting nearly 600,000 ha $(54.7 \%$ exotic plantations and $17.4 \%$ native forests, CONAF 2017). These fires greatly affected high biodiversity hotspot areas (Myers et al. 2000) and altered ecosystems with the highest rates of endemism in the country (Bannister et al. 2012). After this massive catastrophe (both environmental and social), a deep discussion emerged in the country in terms of how to properly restore the large-scale burned areas. Moreover and as never seen before in Chile, the civilian society has shown great interest in topics related to forest landscape restoration, arguing that restoring the fire-affected areas will help to recover ecosystem goods and services for the country. However, a range of relevant questions arise: How will Chile do this? Does the country have the human and technological capacity to implement forest restoration plans at a broad scale? Finally, is there political willingness from the government and policy makers to allocate enough resources from the national budget for this purpose?

In this context, we analyze the state of the art of forest restoration in Chile, the main issues to overcome, and what would be

Author contributions: all authors shared equally in planning and writing of the manuscript; JRB wrote the first draft and all other authors edited and refined the subsequent drafts.

${ }^{1}$ Instituto Forestal, Castro, Chile

${ }^{2}$ Address correspondence to Jan R. Bannister, email jbannister@infor.cl

${ }^{3}$ Laboratorio de Biometría, Departamento de Ciencias Forestales, Universidad de La Frontera, Temuco, Chile

${ }^{4}$ Departamento de Silvicultura y Conservación de la Naturaleza, Universidad de Chile, Santiago, Chile

${ }^{5}$ Instituto Forestal, Concepción, Chile

${ }^{6}$ Instituto de Ecología y Biodiversidad (IEB), Santiago, Chile

${ }^{7}$ Instituto Bosques y Sociedad, Universidad Austral de Chile, Valdivia, Chile

${ }^{8}$ Departamento de Ciencias Biológicas y Biodiversidad, Universidad de Los Lagos, Osorno, Chile

(C) 2018 Society for Ecological Restoration

doi: $10.1111 /$ rec. 12880 


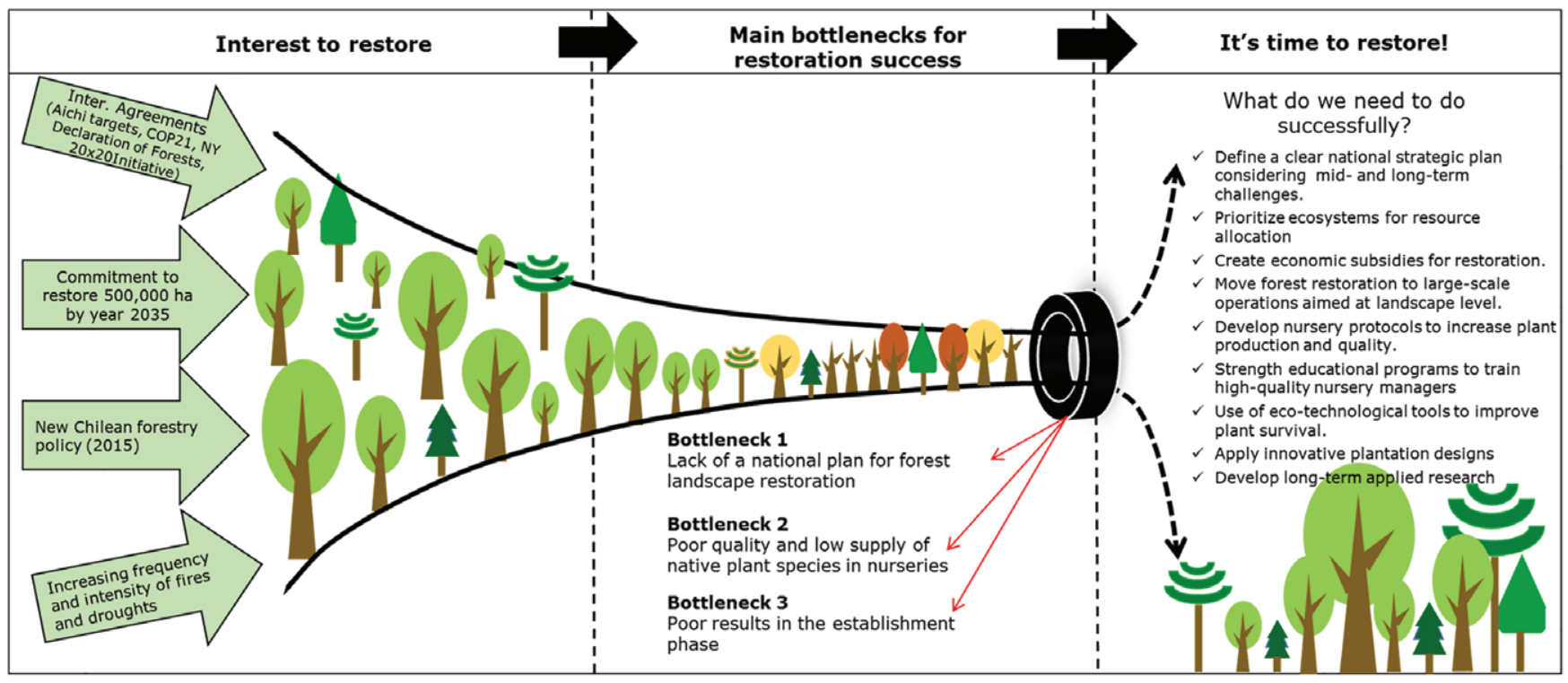

Figure 1. The three major technical bottlenecks that constrain forest landscape restoration in Chile, and what is needed to overcome them.

the pragmatic steps to accomplish these forest landscape restoration challenges. We focused on how to promote the implementation of forest restoration initiatives with native species in the different biogeographic regions of Chile at a broader landscape scale. Here, we summarize and discuss the three major technical bottlenecks that constrain forest landscape restoration in Chile, and provide insights on how to overcome them (Fig. 1). We emphasize the discussion regarding active restoration (e.g. plantation of native tree species), since most of the available information and experiences in Chile use this approach.

\section{The Current Scenario of Forest Restoration in Chile}

Under the current scenario, the goal of restoring over 500,000 ha by the year 2035 seems impossible. Despite the fact that an Ecological Restoration Network was created in Chile in 2015 that included researchers, professionals, and restoration practitioners, forest restoration is still an emerging discipline in Chile (Smith-Ramírez et al. 2015; Bannister et al. 2016). To the best of our knowledge, there is no comprehensive information regarding how much land has been restored to date in Chile. A recent review by Smith-Ramírez et al. (2015) reported that there have been circa 60 restoration experiences across different types of vegetation in Chile. Most of these efforts are small-scale experiences (i.e. $<1$ ha), with very few initiatives encompassing large areas (i.e. $>100$ ha) (Smith-Ramírez et al. 2015). More constraining is the fact that most forest restoration experiments in Chile are often maintained and monitored only for a short-term period, mainly due to the short span of research grants (2-4 years).

According to official data, in Chile between 1998 and 2015, 8,032 ha of plantations were established with native species, an average of 472 ha per year (CONAF 2016a). Not all plantations have been designed with the goal of restoring degraded lands. For example, several regions have been planted for commercial timber production. Nevertheless, most forest restoration experiences in Chile are based on active approaches. In this context, the plantation rate with native tree species between 1998 and 2015 (17 years) allows an understanding about the country's current operational capacity to actively restore degraded forests with native species. The most planted tree species during this period were Prosopis chilensis (1,565 ha), Quillaja saponaria (1,474 ha), Nothofagus dombeyi (1,020 ha), and Araucaria araucana (979 ha). Considering this plantation rate, Chile would need over 1,000 years to achieve the national target of restoring 500,000 ha by 2035 . In contrast, within the same period (1998-2015), circa 1.8 million hectare of exotic plantations were established nationwide (CONAF 2016a). This pattern of planting more exotic than native tree species is also found in a number of other countries, including China (Xu 2011), South Korea (Temperton et al. 2014), Brazil (FRA 2015a), and Argentina (FRA 2015b). In Chile, since 1974, the increasing plantation rate using exotic species was facilitated by the application of a subsidy for forest companies, which provided up to $75 \%$ of forestation costs. This phenomenon greatly helped to stimulate the industrial forest sector in Chile, becoming the second largest national export (INFOR 2016), contributing about $2.6 \%$ to total GDP (Salas et al. 2016). A controversial issue has emerged from the rapid expansion of industrial plantation using exotic species, which is related to the conversion of native forests to exotic plantations (Zamorano-Elgueta et al. 2015; Miranda et al. 2017). Nowadays, in order to maintain the FSC (Forest Stewardship Council) certification, forest companies have to convert over 45,000 ha of exotic plantations to native forests (Prado 2015). This challenge also represents an enormous opportunity for forest landscape restoration in Chile. 


\section{Bottlenecks for Forest Restoration in Chile}

\section{Lack of a National Plan for Forest Landscape Restoration}

Chile has the urgent need for a national long-term strategic plan for forest landscape restoration. Currently, forest restoration strategies have been carried out independently between forest companies, government agencies, and research groups (Hernández et al. 2012; Smith-Ramírez et al. 2015; Bannister et al. 2016). Furthermore, intense discussions after the catastrophic wildfires of 2017 brought to light the lack of a well-defined strategic plan for forest landscape restoration.

Restoration of forest landscapes should be an option in both public and private sectors, since degradation occurs on both types of land. Therefore, a strategic plan should include a wide range of restoration options (Stanturf et al. 2017), explicitly considering mid- and long-term objectives (i.e. 5-20 years), with the aim of creating more functional landscapes and reducing the negative impacts of monocultures on biodiversity and society (Brockerhoff et al. 2008; Andersson et al. 2016). Secondly, different actors and stakeholders must collaborate together to prioritize ecosystems and regions for adequate resource allocation into restoration plans (Menz et al. 2013). For instance, the most likely outcome from passive restoration (e.g. natural regeneration) should be considered before even thinking about actively restoring or planting a given area (Holl $\&$ Aide 2011). Also, the identification of areas where multiple functions operate at different scales (Schulz \& Schröder 2017), would help to prioritize forest restoration within hotspots of high value for biodiversity conservation, resulting in real, practical solutions for forest restoration (Bannister et al. 2016). The Brazilian Atlantic Forest Restoration Pact (Brancalion et al. 2013; Pinto et al. 2014) represents a good example of well-organized forest restoration on a large scale. Thirdly, considering the extremely low plantation rates with native species, the national strategic plan should strongly encourage higher economic subsidies to land owners willing to restore. This should be similar to what was applied in the 1970s for mainly exotic plantations, but with a strong focus on forest restoration with native species suitable for each ecosystem type.

Finally, to overcome these restoration challenges in Chile, the proposed national strategic plan should move forest restoration forward, from theoretical models and small-scale experiments, to large-scale operations aimed at restoring the entire landscape (Holl et al. 2003). Up scaling from plot-based experiments to landscape-scale programs has proven to be difficult worldwide. However, identifying key focal regions, increasing research to fill up knowledge gaps, creating active restoration networking with key actors and stakeholders, and ensuring political viability are all mechanisms that can help achieve Chile's forest restoration goals (Menz et al. 2013).

\section{Poor Quality and Low Supply of Native Plant Species}

A significant increase in the supply, diversity, and quality of native plant species in local nurseries is urgently needed. According to CONAF (2016b), Chilean nurseries could supply a total of circa 10 million seedlings of 87 different native tree species. This situation heavily contrasts with the supply of almost 70 million seedlings of the exotics Pinus radiata and Eucalyptus spp. available for industrial purposes (CONAF $2016 b$ ). Besides the low number of native seedlings, their quality is generally poor. In fact, if only seedlings with a "minimum planting quality" are considered (equivalent to one-season bare root and speedling seedlings with a maximum height of $80 \mathrm{~cm}$ ), the total supply of native seedlings would drastically decrease to less than 3.4 million (CONAF 2016b). Thus, to achieve the forest landscape restoration challenges for Chile within the next few decades, there is a need for at least 250 million native seedlings (considering at least 500 seedlings per hectare). It is recognized that the lack of a sufficient supply of diverse and good-quality seedlings is a critical problem for forest restoration programs worldwide (Haase \& Davis 2017; Jalonen et al. 2017). However, good progress has been made to counter this situation (Moreira da Silva et al. 2017).

There is a well-documented positive relationship between seedling quality and successful restoration for numerous tree species (Villar-Salvador et al. 2012; Oliet et al. 2013; Ovalle et al. 2016). For better seedling quality, native plant producers in Chile need a technological leap to improve and update their production protocols, infrastructure, and materials in their nurseries. Currently, there is only one Chilean norm (although relatively general and voluntary, INN 2006) regarding seedling quality that establishes standards for genetic, physiological, and morphological quality for the main exotic tree species in Chile (Pinus radiata, Eucalyptus globulus, Eucalyptus nitens, and Pseudotsuga menziesii). Only one native tree species (Nothofagus alpina) is included in the norm. Despite the fact that the Chilean Forest Research Institute (INFOR) and a number of Chilean universities have developed nursery protocols for better production of native species (Santelices et al. 2011; García 2014; Donoso et al. 2015), there is no official, regulatory implementation of these protocols. For instance, better standards for plant production should be site-specific, taking into account the wide range of biogeographic regions of the country.

In this context, applying the target plant concept (Dumroese et al. 2016) in Chile could provide a more flexible framework that would benefit nursery managers and their customers by improving the survival and growth rates of native seedlings. This concept emphasizes field performance of tree seedlings, rather than performance in nursery conditions. Thus, promoting a partnership between nurseries and their customers in determining the target plant that is needed based on site characteristics, would significantly contribute to better results for forest restoration (Dumroese et al. 2016). We underline our belief that the creation of more plant nurseries and the strengthening of educational programs to train high-quality nursery personnel (e.g. managers and technicians) is an urgent need. The Chilean Forest Service (CONAF) and INFOR have an important role to play in promoting the production of high-quality seedlings and increasing the plant supply to accomplish the forest landscape restoration challenges previously described. These changes would help to more accurately inform nursery managers about the amount of seedlings that are needed in a realistic timeframe, allowing managers to plan accordingly to meet the increasing demand. 




Figure 2. Examples of different establishment techniques that increase the performance of native tree species in the field. (A) Maytenus boaria and Quillaja saponaria seedlings growing in shelter tubes in central Chile $\left(33^{\circ} \mathrm{S}\right)$; (B) and (C) cluster plantings with Nothofagus allesandri in the coastal range of central Chile $\left(35^{\circ} \mathrm{S}\right)$ underneath artificial shade; (D) cluster plantings with Nothofagus dombeyi and Proteaceae Embothrium coccineum in the Andes of south-central Chile $\left(38^{\circ} \mathrm{S}\right)$; (E) seedlings of the native conifer Pilgerodendron uviferum established underneath shrubland canopies for protection in north Patagonia $\left(43^{\circ} \mathrm{S}\right)$; (F) Nothofagus pumilio sapling being protected by log piles to diminish strong wind incidence in southern Patagonia (52 $\mathrm{S}$ ). Photos by: Juan Ovalle (A),

CTPF (B, C), Rodrigo Vargas (D); Jan Bannister (E); Patricio Valenzuela (F).

\section{Poor Results in the Establishment Phase}

In Chile, there is increasing evidence showing that by manipulating key environmental and microsite factors, survival rate and early performance of native species can be significantly improved (Soto et al. 2015; Valenzuela et al. 2016; Soto et al. 2017). The use of eco-technological tools such as tree shelters, fertilizers, organic amendments, and polymer hydrogels following site preparation are common forest restoration practices that help to diminish the early stress of seedlings, reducing browsing and increasing plant growth (Piñeiro et al. 2013). These eco-technologies mimic some key attributes from natural ecosystems and enhance microclimatic conditions by reducing the effect of solar radiation or water stress (Vallejo et al. 2012, Fig. 2).
Preliminary results of forest restoration initiatives in central and south-central Chile $\left(33-36^{\circ} \mathrm{S}\right)$ highlight the importance of using shelter tubes for drought-resistant species like Quillaja saponaria, since they effectively control the excessive solar radiation during the first summer season after outplanting (Arellano, unpublished data). Likewise, a significant increase in seedling survival from 25 to $90 \%$ was reported for Nothofagus obliqua, Laurelia phillipiana, and Aextoxicon punctatum when seedlings were protected with mesh guards upon plantation (INFOR, unpublished data). In northern Patagonia $\left(43^{\circ} \mathrm{S}\right)$, planted seedlings of the native conifer Pilgerodendron uviferum showed $200 \%$ higher growth when seedlings were established underneath a nurse canopy (Bannister 2015). Also in northern Patagonia, the use of tree shelters had a positive effect in reducing browsing by Nothofagus antarctica seedlings established 
in canopy gaps within degraded forests (Promis, unpublished data) (Fig. 2).

All the above-presented evidence suggests the urgent need for novel plantation designs (e.g. nonhomogeneous, group planting, underneath nurse canopies) to promote successful results (e.g. increased survival and growth rates) when carrying out forest restoration at broader landscape scales. A promising approach for the increase of species diversity in degraded forests is planting native tree species in groups that complement natural regeneration (Rey Benayas et al. 2008; Bannister et al. 2016; Saha et al. 2016). This approach mimics the natural pattern of several tree species and has positive long-term effects at landscape scales (Bannister 2015). In south-central Chile $\left(38^{\circ} \mathrm{S}\right)$, a group of trials including shade-intolerant Nothofagus species and Proteaceae species were established to evaluate seedling performance under two planting treatments: regular row planting vs. group planting. After one growing season, the survival rate for both species significantly increased from $45 \%$ in rows to $65 \%$ in groups (Llanquilef 2017).

\section{How to Begin to Overcome These Three Bottlenecks?}

In light of the evidence presented in this article, there is a need for more systematized, long-term, and applied research about forest restoration. This will transversely help to overcome (at least in part) the lack of a plan for forest landscape restoration in the country, the poor quality and low supply of native plant species in Chilean nurseries, and the poor results by forest restoration initiatives in Chile. The importance of efficiently utilizing available resources when restoring big landscapes makes it necessary to properly systematize the few restoration initiatives available in the country. In this sense, forest restoration experiments implemented at broader spatiotemporal scales should be encouraged and better funded, due to their valuable contribution for assessing critical phases of plant establishment. This will be also helpful for translating theoretical concepts into practical solutions, and therefore, better informed policy makers (Bannister et al. 2016). Promoting similar experiments in different ecosystems can be also useful for identifying general patterns, which in turn increases research applicability. Beyond experiments, forest restoration should be efficient to become extensive and successful.

\section{Acknowledgments}

We thank the administration and staff of the Tantauco Park for helping to organize the "II Chaiguata Forest Restoration Workshop" that gave us the opportunity to meet and discuss the topics included in this article. J.R.B. thanks FONDECYT N ${ }^{\circ} 11160191$ and the Chilean Ministry of Agriculture (MINAGRI) for funding this research. R.V.G. extends thanks to FONDECYT N¹1170987 and to Project FIBN N022/2018. J.F.O. thanks the Center of Applied Ecology \& Sustainability (CONICYT FB0002-2014) and SuFoRun Project $\mathrm{N}^{\circ}$ 691149. A.F.R. thanks to FONDECYT $\mathrm{N}^{\circ} 11150487$ and to CONICYT-PAI $\mathrm{N}^{\circ} 79170054$. P.J.D. thanks FONDECYT $N^{\circ} 1150496$. A.P. thanks Project FIBN N012/2014. We also thank the three anonymous reviewers and the editor for their valuable comments and suggestions that helped improve this manuscript, and to Ian Scott Kinney for his editorial revisions in the English language.

\section{LITERATURE CITED}

Andersson K, Lawrence D, Zavaleta J, Guariguata MR (2016) More trees, more poverty? The socioeconomic effects of tree plantations in Chile, 2001-2011. Environmental Management 57:123-136

Bannister JR (2015) Recuperar bosques no es solo plantar árboles: lecciones aprendidas luego de 7 años restaurando bosques de Pilgerodendron uviferum (D. Don) Florin en Chiloé. Anales del Instituto de la Patagonia 43:35-51

Bannister JR, Vidal OJ, Teneb E, Sandoval V (2012) Latitudinal patterns and regionalization of plant diversity along a $4270-\mathrm{km}$ gradient in continental Chile. Austral Ecology 37:500-509

Bannister JR, Donoso P, Mujica R (2016) La silvicultura como herramienta para la restauración de bosques templados. Bosque 37:229-235

Brancalion PH, Viani RA, Calmon M, Carrascosa H, Rodrigues RR (2013) How to organize a large-scale ecological restoration program? The framework developed by the Atlantic Forest restoration pact in Brazil. Journal of Sustainable Forestry 32:728-744

Brockerhoff EG, Jactel H, Parrotta JA, Quine CP, Sayer J (2008) Plantation forests and biodiversity: oxymoron or opportunity? Biodiversity and Conservation 17:925-951

CONAF (2015) Política Forestal 2015-2035. Corporación Nacional Forestal, Santiago, Chile

CONAF (2016a) Plantaciones Forestales 1970 al 2015 http://www.conaf.cl/ nuestros-bosques/bosques-en-chile/estadisticas-forestales/ (accessed 5 May 2017)

CONAF (2016b) Base de datos viveros forestales 2016 http://www.conaf.cl/ nuestros-bosques/bosques-en-chile/viveros/ (accessed 5 May 2017)

CONAF (2017) Análisis de la Afectación y Severidad de los incendios Forestales ocurridos en enero y febrero de 2017 sobre los usos de suelo y los ecosistemas naturales presentes entre las regiones de Coquimbo y Los Ríos de Chile. Informe Técnico. Corporación Nacional Forestal, Santiago, Chile

Donoso P, Navarro C, Soto D, Gerding V, Thiers O, Pinares J, Escobar B, Sanhueza MJ (2015) Manual de plantaciones de raulí (Nothofagus alpina) y coihue (Nothofagus dombeyi) en Chile. Universidad Católica de Temuco, Temuco, Chile

Dumroese KR, Landis TD, Pinto JR, Haase DL, Wilkinson KW, Davis AS (2016) Meeting forest restoration challenges: using the target plant concept. Reforesta 1:37-52

FRA (2015a) Global forest resources assessment 2015. In: Country Report. FAO, Brazil, Rome

FRA (2015b) Evaluación de los recursos forestales mundiales 2015. In: Informe Nacional. FAO, Argentina, Rome

García D (2014) Efecto de la fertilización nitrogenada en las características morfológicas en plantas de Nothofagus nervosa (P. et E.) Oerst. producidas en vivero. Forest Engineer thesis, Universidad de Concepción, Concepción. Chile

Haase DL, Davis AS (2017) Developing and supporting quality nursery facilities and staff are necessary to meet global forest and landscape restoration needs. Reforesta 4:69-93

Hernández A, Langdon B, Ramirez de Arellano P (2012) Plan de restauración de bosque nativo forestal Arauco. Gerencia de desarrollo forestal Arauco, Concepción, Chile

Holl KD, Aide TM (2011) When and where to actively restore ecosystems? Forest Ecology and Management 261:1558-1563

Holl KD, Crone EE, Schultz CB (2003) Landscape restoration: moving from generalities to methodologies. AIBS Bulletin 53:491-502 
INFOR (2016) El sector forestal chileno 2016. Área de Información y Economía Forestal, Instituto Forestal, Santiago, Chile

INN (2006) Norma de Calidad. Madera - Material de propagación de uso forestal. Norma NCh 2957 2013. Instituto Nacional de Normalización, Santiago, Chile

Jalonen R, Valette M, Boshier D, Duminil J, Thomas E (2017) Forest and landscape restoration severely constrained by a lack of attention to the quantity and quality of tree seed: insights from a global survey. Conservation Letters 11:e12424

Llanquilef F (2017) Evaluación del establecimiento de especies nativas para la reconversión de una plantación de Pseudotsuga menziesii (Mirb. Franco) a bosque Nativo en el predio Marsella. Parque Nacional Conguillío, Universidad de La Frontera, Temuco, Chile

Mandle L, Bufford JL, Schmidt IB, Daehler CC (2011) Woody exotic plant invasions and fire: reciprocal impacts and consequences for native ecosystems. Biological Invasions 13:1815-1827

Menz MH, Dixon KW, Hobbs RJ (2013) Hurdles and opportunities for landscape-scale restoration. Science 339:526-527

Miranda A, Altamirano A, Cayuela L, Lara A, González M (2017) Native forest loss in the Chilean biodiversity hotspot: revealing the evidence. Regional Environmental Change 17:285-297

Moreira da Silva AP, Schweizer D, Rodrigues-Marques H, Cordeiro-Teixeira AM, Nascente dos Santos TVM, Sambuichi RHR, Badari CG, Gaudare U, Brancalion PHS (2017) Can current native tree seedling production and infrastructure meet an increasing forest restoration demand in Brazil? Restoration Ecology 25:509-515

Myers N, Mittermeier RA, Mittermeier CG, Da Fonseca G, Kent J (2000) Biodiversity hotspots for conservation priorities. Nature 403:853-858

Oliet J, Puértolas J, Planelles R, Jacobs DF (2013) Nutrient loading of forest tree seedlings to promote stress resistance and field performance: a Mediterranean perspective. New Forests 44:649-669

Ovalle JF, Arellano EC, Oliet JA, Becerra P, Ginocchio R (2016) Linking nursery nutritional status and water availability post-planting under intense summer drought: the case of a south American Mediterranean tree species. iForest 9:758-765

Piñeiro J, Maestre FT, Bartolomé L, Valdecantos A (2013) Ecotechnology as a tool for restoring degraded drylands: a meta-analysis of field experiments. Ecological Engineering 61:133-144

Pinto SR, Melo F, Tabarelli M, Padovesi A, Mesquita CA, de Mattos CA, et al. (2014) Governing and delivering a biome-wide restoration initiative: the case of Atlantic Forest Restoration Pact in Brazil. Forests 5:2212-2229

Prado JA (2015) Plantaciones forestales. Más Allá de los Árboles. Colegio de Ingenieros Forestales, Chile

Rey Benayas JM, Bullock JM, Newton AC (2008) Creating woodland islets to reconcile ecological restoration, conservation, and agricultural land use. Frontiers in Ecology and the Environment 6:329-336
Saha S, Kuehne C, Bauhus J (2016) Lessons learned from oak cluster planting trials in Central Europe. Canadian Journal of Forest Research 47:139-148

Salas C, Donoso PJ, Vargas R, Arriagada CA, Pedraza R, Soto DP (2016) The forest sector in Chile: an overview and current challenges. Journal of Forestry 114:562-571

Santelices R, Navarro-Cerrillo RM, Drake F (2011) Propagation and seedling cultivation of the endemic species Nothofagus alessandrii Espinosa in Central Chile. Restoration Ecology 19:177-185

Schulz JJ, Schröder B (2017) Identifying suitable multifunctional restoration areas for Forest landscape restoration in Central Chile. Ecosphere 8:1-27

Smith-Ramírez C, González ME, Echeverría C, Lara A (2015) Estado actual de la Restauración ecológica en Chile, perspectivas y desafíos. Anales del Instituto de la Patagonia 43:11-21

Soto DP, Donoso PJ, Salas C, Puettmann KJ (2015) Light availability and soil compaction influence the growth of underplanted Nothofagus following partial shelterwood harvest and soil scarification. Canadian Journal of Forest Research 45:998-1005

Soto DP, Jacobs DF, Salas C, Donoso PJ, Fuentes C, Puettmann KJ (2017) Light and nitrogen interact to influence regeneration in old-growth Nothofagus-dominated forests in south-Central Chile. Forest Ecology and Management 384:303-313

Stanturf J, Mansourian S, Kleine M (2017) Implementing forest landscape restoration: a practitioner's guide. International Union of Forest Research Organization (IUFRO), Vienna, Austria

Temperton VM, Higgs E, Choi YD, Allen E, Lamb D, Lee CS, Harris J, Hobbs RJ, Zedler JB (2014) Flexible and adaptable restoration: an example from South Korea. Restoration Ecology 22:271-278

Ubeda X, Sarricolea P (2016) Wildfires in Chile: a review. Global and Planetary Change 146:152-161

Valenzuela P, Arellano EC, Burger JA, Becerra P (2016) Using facilitation microsites as a restoration tool for conversion of degraded grasslands to Nothofagus forests in Southern Patagonia. Ecological Engineering 95:580-587

Vallejo R, Smanis A, Chirino E, Fuentes D, Valdecantos A, Vilagrosa A (2012) Perspectives in dryland restoration: approaches for climate change adaptation. New Forests 43:561-579

Villar-Salvador P, Puértolas J, Cuesta B, Peñuelas JL, Uscola M, Heredia-Guerrero N, Rey-Benayas JM (2012) Increase in size and nitrogen concentration enhances seedling survival in Mediterranean plantations. Insights from an ecophysiological conceptual model of plant survival. New Forests 43:755-770

Xu J (2011) China's new forests aren't as green as they seem. Nature 477:371

Zamorano-Elgueta C, Benayas JMR, Cayuela L, Hantson S, Armenteras D (2015) Native forest replacement by exotic plantations in southern Chile (1985-2011) and partial compensation by natural regeneration. Forest Ecology and Management 345:10-20

Received: 6 September, 2017; First decision: 31 October, 2017; Revised: 22 August, 2018; Accepted: 22 August, 2018 